\title{
Local Community Attitude and Perceptions towards Tourism Conservation Policies in Rwanda Case of Volcanoes National Park
}

\author{
Kalulu Ronald*, Tushabe Emmy, Nsabimana Emmanuel \\ Department of Travel and Tourism Management, University of Tourism, Technology and Business Studies (former RTUC), Rwanda
}

Copyright $\bigcirc 2016$ by authors, all rights reserved. Authors agree that this article remains permanently open access under the terms of the Creative Commons Attribution License 4.0 International License

\begin{abstract}
Volcanoes National Park contains the rich biodiversity that attracts many tourists. Despite being an attractive destination, Volcanoes National Park is facing different threats resulting from human activities including poaching, hunting, bamboo collection, and others although policies to conserve the VNP were set up. It was due to these challenges that the study was conducted to investigate the local community attitude and perception towards conservation policies around the Park. It was based on Nyange Sector in three cells selected as they were around the VNP. These cells included Kabeza, Muhabura, and Ninda. The objectives of the study were; i) to establish the whether the local residents understood well the park conservation policies, ii) to assess the role of local communities in park conservation, iii) to find out the factors deterring conservation policy implementation in VNP. Data were collected from cells contacting 45 respondents selected conveniently. The questionnaire and interview method were used to collect data. The study revealed that most local people understood well and were aware of the existing conservation policies and rules. The most common policies included; punishment to hunters, bush burners, and poachers; increasing the investment and financing $(5 \%$ revenue sharing policy); developing infrastructure leading to the park; capacity building and human resources motivation; marketing and awareness reinforcement and finally supporting local community small businesses among others. The study found out that local people were somehow satisfied with some policies with exception of setting a wall of separation, and punishment of poachers. The study further revealed that local Residents play a big role in the conservation of VNP and that decision making process in matter of VNP conservation is important to the park managers where they interact and share views with local government in decisions making in terms of VNP conservation. Despite the policies already existing, the implementation of them encounters barriers including but not limited to; excessive forest resources dependency where people still have the mentality of hunting and poaching for meat and collect bamboo for basketry. These result in
\end{abstract}

harming the park and the flora and fauna it shelters. Recommendations mainly focused on the increase of the awareness of conservation policies of Volcanoes National Park as well as putting more conservation policies with the involvement of community leaders and residents.

Keywords Tourism, Conservation, Local Residents, Policies, Implementation

\section{Background}

Volcanoes National Park (VNP) is a home to the rare mountain gorillas up to the summit of Karisimbi. It is from this area that Rwanda's tourism revenue is mostly based due to gorilla tourism. Due to the nature of the gorilla tourism and given its contribution to national income in the country, the government of Rwanda through its department RDB-tourism department, has come up with policies that can sustain the park as well as benefit local residents economically, socially and environmentally (RDB, 2015) even though local people were not fully involved in making these policies hence most residents surveyed feel as if they are not of the park. Some of the policies include punishment to hunters, bush burners, and poachers; increasing the investment and financing, capacity building and human resources motivation; marketing and awareness reinforcement; establishment of a separation wall between the park and local community; supporting local small and medium local enterprises; 5\% Tourism Revenue Sharing; tourism infrastructure development and strengthening social identity.

Although the above policies are good for conservation, they were received with mixed feelings by the local residents who surround the park and who base on the Park Forest to for subsistence earning given the fact that they live in high levels of poverty (Munanura, Backman \& Sabuhoro, 2013). These park neighbors total to about 27,560 residents of Nyange Sector grouped in 12,810 households in the cells of Ninda, 
Muhabura, and Kabeza. The local residents also expect a lot from the park in form of food, freedom to use the forest resources, jobs and revenue sharing but they receive little. This make them feel as if they are not part of park thus park conflicts with greater influence and impact to the park's ecological systems for example, wildfire due to honey harvesting, poaching, timber harvesting among others are still present in volcanoes national park. In addition, the local communities expect a lot from revenue sharing but they receive little hence local communities resent by penetrating the park for forest resources. Therefore, the local community perception and attitude about VNP is attributed to the park strict conservation policies which deprive local community residents of the available opportunities in the park. Therefore, the study investigated the attitude and perceptions of the local community about tourism conservation policies around Volcanoes National Park so that appropriate measures are devised. This is in line with Sanchez et al., (2009) studies which depict advocated for involvement of local residents in making park decisions. The study objectives were i) to establish the whether the local residents understood well the park conservation policies, ii) to assess the role of local communities in park conservation, iii) to find out the factors deterring conservation policy implementation in VNP.

\subsection{Context /Review of Literature}

Conservation is involves improvement, and protection of human and natural resources in a wise manner, ensuring derivation of their highest economic and social benefits on a continuing on long-term basis. Conservation is achieved through alternative technologies, recycling, and reduction in waste and spoilage and (unlike preservation) implies consumption of the conserved resources. Dian Crazy et al (2003:49) says that the local community is a locality of people who live in the area and have the same believes, understanding, attitude and the way of acting on a certain situation.

\section{Volcanoes National Park}

Today, mountain gorilla tourism remains the foundation of tourism success at VNP, and for this reason, VNP forms the backbone of tourism in Rwanda. Other attractions have since been developed at VNP, including visits to the crater lakes, bird treks, mountain climbing, and musanze rocks among others, which have contributed to the growth of tourism at VNP. However, none of these attractions has the appeal that mountain gorilla tourism has. For example, over 80 percent of tourists to VNP are mountain gorilla visitors and Poor household participants perceive poverty in terms of food insecurity attributed to the lack of land and destruction of crops by wild animals from the park. When this happens, the livelihoods of the poor depend on income or food they obtain from their neighbors' fields, it is clear that poor families either spend days and nights guarding their fields from wild animals or pursue employment from their neighbors further away from the forest to meet their livelihoods needs (Nielsen \& Spenceley, 2010). Tourism numbers at VNP have been increasing since 1974 when ORTPN was created (ORTPN, 2005). However the trend significantly increased in 1979 upon the introduction of mountain gorilla tourism (Nielsen and Spenceley, 2010). During the civil war and genocide between 1990 and 1994, tourism at VNP virtually disappeared. For example, annual tourist numbers went from 39,000 in 1984 to less than 1,000 tourists in 1994 (Nielsen and Spenceley, 2010). Since security returned in the country in 1995, tourism has increased every year (Munanura et al., 2013). For example since 2010, over 20,000 visitors per year have toured VNP generating, in 2011, annual tourism revenue of over 10 million US dollars for Rwanda (RDB, Unpublished report).

It is believed by the government and stakeholders promoting tourism at VNP that mountain gorilla tourism is successful, economically beneficial, and creates incentives for conservation support among local residents (Nielsen \& Spenceley, 2010; Bush et al., 2010). However, it is suggested that the poorest local residents living in close proximity to parks in the Albertine Rift, who depend on the park whose actions threaten wildlife (Bush et al., 2010). Despite its success, is not helping to address the main human-induced threat to wildlife, which is the human dependence on forest resources for subsistence livelihoods by the poorest households living in proximity to wildlife areas. It has been documented that forest dependence and threats to wildlife at VNP has continued, despite numerous tourism benefit opportunities extended to park neighboring communities (Kalpers et al., 2003, Plumptre et al., 2004, Martin et al., 2011). This is due to failure by tourism benefits to offset the costs of coexisting with wildlife (Walpole and Thieles, 2003) and that only the elite society benefits more from tourism than the ordinary person who is dependent on forest resources for a living (Walpole \& Godwin, 2000).

\section{Benefits of Volcanoes National Park to the community}

In 1974, the Office Rwandais de Tourisme et de Parc Nationaux (ORTPN) was created by presidential decree and given the mandate to manage national parks in Rwanda (ORTPN, 2005). In 2008, ORTPN was merged with other government organizations to form the Rwanda Development Board (RDB). It is through the RDB that tourism promotion and biodiversity conservation became part of a wider mandate to promote economic development in Rwanda. VNP presents a unique, high altitude part of the Albertine Rift, which is recognized as one of the most critical ecosystems for conservation in the world (MacKinnon and MacKinnon, 1986). With varying altitudinal range, VNP is characterized by distinctive zones of open montane forest, bamboo, sub-alpine and afroalpine vegetation (ORTPN, 2005). This has seen increment of tourists numbers and the eventual Forex earning and tax to the government at VNP since 1974 when ORTPN was created (ORTPN, 2005), (RDB, Unpublished report). The park has also been of great benefit to local residents in form of local employment; community improvement due to conserved nature, protection 
of the environment as well as community projects that are funded by the $5 \%$ TRS such as schools, health facilities, tourism infrastructure, and a number of income generation activities.

Volcanoes National Park (VNP) Policy Measures To Conserve the Park

- Setting a wall of separation

- Creation of small, and medium enterprises to residents

- Revenue sharing at 5\%

- Infrastructure development

- Land availability and adequate tenure

- Punishment to hunters, bush burners, and poachers

- Increase the investment and financing

- Capacity building and human resources motivation

- Marketing and awareness reinforcement

- Interaction and sharing views with the local government in terms of conservation of VNP

- Active participation in marketing VNP tourism potential

- Seek partnership opportunities with tourism private companies

- Information to park managers about the people who harm the park

- Attending the conference discussing about the VNP conservation

Challenges facing the park

Despite such importances, there are many threats to this biodiversity caused by human activities based on their dependence on forest resources to supplement livelihoods (Bush et al., 2010). Some of these threats, such as mining, poaching for bush-meat, timber harvests, wood harvests for handicrafts, medicinal plants, minerals, honey gathering that also causes fire outbreaks, construction, fire, and illegal honey gathering that often results into fire outbreaks (Plumptre et al., 2004) and many others, all of which have led to significant deforestation and degradation of this rather fragile mountain gorilla habitat in the AR (Plumptre et al., 2004). It has also resulted into significant habitat loss that directly threatens already endangered species such as mountain gorillas (Plumptre et al., 2003, 2004, 2007). For example, since the mid-1980s, about 1560 square kilometers of forest cover has been lost and converted to other land uses in the Albertine Rift (Plumptre et al., 2007). The increasing civil war in Democratic Republic of Congo (DRC) has seen most of the refugees wanting to stay in the park or attempt to use it for survival. These wars have made it impossible for organized and effective law enforcement and conservation efforts (Bush et al., 2010) and (Martin et al., 2011; Plumptre et al., 2003). Others human-induced threats to conservation are caused by residents in extreme poverty living in close proximity to protected areas (Adams \& Infield, 2003; Brandon \& Wells, 1992; Plumptre et al., 2004).

In a recent study at VNP, it was observed that while revenue sharing has improved attitudes of many local residents by investing back tourism income, it is has done little to change behavior of those at park periphery that most threaten the park (Bush et al., 2010). One of the preconditions for tourism benefits to have a conservation impact is that benefits have to be targeted at poor local residents in communities neighboring protected areas (Bush et al., 2010).

The impact of policy implementation on local communities around the Volcanoes National Park (VNP)

Despite the importance of the policy, many residents still view it as a way of depriving them freedom to use the park resources as most of them are poor and depend on subsistent farming and dependence on forest resources to supplement livelihoods (Bush et al., 2010). This not only limits the conservation efforts but also culminate into conflicts between park managers and the local residents. For example there still exist illegal hunting, honey harvest and many other activities which posse threat to the park. The implementation phase of the revenue sharing projects is the most important stage where linkages with conservation need to be emphasized to maintain consistency, and to have post-funding dialogues that reinforce the project link with conservation. It is recommended that a schedule of regular supervisory and consultation meetings be planned by community conservation officers to uncover and address limitations for effective implementation of funded programs. Enforcement for a link to be created in the minds of revenue sharing beneficiaries, community groups that benefit should be organized and involved in biodiversity threat monitoring and law enforcement activities. By involving these community groups, a direct connection between their funded projects and the expected biodiversity conservation benefits can be created in their minds. This will allow the government to transfer biodiversity conservation responsibilities to the communities neighboring the park. This has the potential to create a tolerance for wildlife conservation costs as well as helping to build trust between communities and the government that has traditionally been lacking.

The government of Rwanda has contributed significantly to fund conservation of national parks from the tourism revenue. Communities have also benefited directly from tourism by selling their local artisan products and establishing small-scale tourism-based businesses. Indirectly, local residents have benefited through the government's revenue-sharing scheme and employment opportunities in the tourism sector. For example the 5 percent revenue sharing builds schools and other community infrastructures but does not protect their potato fields from wild animals. To them, the benefits will not be appreciated until compensation is in place for crop raiding. The people here want direct benefits, not the indirect benefits that revenue sharing supports is also important for its contribution to the wellbeing and economy of the residents neighboring the park and the country in general (Plumptre et al., 2004; Weber, 1987). This is an indication that compensation policies in the pipeline might be helpful in addressing some of these concerns. 


\section{Methodology}

The study was cross sectional thus used both qualitative and quantitative designs to obtain data about local community attitude and perception about Rwanda's tourism conservation policies around Volcanoes National Park. A questionnaire was used in addition to interview method to obtain data from fifteen representatives of fifteen households in each of 3 cells of Ninda, Muhabura, and Kabeza sectors around the VNP. Convenience sampling technique was used where 45 respondents represented 3969 households selected. Local community residents and park leaders were selected for the study. All questionnaires were self-administered and consisted of closed ended questions and a few open -ended questions for purposes of clarity. The study used both primary and secondary sources of data. Primary data was obtained from local residents and park employees. Secondary data was obtained from the review of literature in journals and books obtained from the internet as well as libraries. The study also used observation method where the researcher independently observed behaviours, responses and feelings as well as the structural and physical set up of park.

\section{The Results}

As shown in the histogram above, the respondents were aged from 18 years and above. The respondents aged from 18 to 30 years old were more involved in the study than others. They were 24 out of 45 which covers $53.3 \%$ of all respondents. The second group in majority was that one ranging between 31 years old and 40 occupying 24.4\% (11 respondents). Other groups were not significantly represented. $15.6 \%$ for respondents of above 50 , and 6.7 of respondents aged in the range between 41 and 50 years. The high representativeness of the respondents ranging between 18 and 40 years have a significance in the maturity, understanding and quick adaptation to new government policies in terms of tourism and conservation of VNP.

The respondents were nearly balanced in gender where male respondents were 24 standing for $53 \%$ while female respondents were 21 out of 45 ( $47 \%$ of all respondents). This has a positive effect in understanding where both male and female have a view on tourism issues. The table illustrates that although the large number of respondents attended the primary school only, there were another significant segment of respondents. This is hold by respondents who attended the secondary level $(33.3 \%)$. In fact, because there are few secondary schools in these sectors, the number of people who attended schools is not significant. However, being in the proximity of the park, they know something about VNP. The table illustrates that although the large number of respondents attended the primary school only, there were another significant segment of respondents. This is hold by respondents who attended the secondary level (33.3\%). In fact, because there are few secondary schools in these sectors, the number of people who attended schools is not significant. However, being in the proximity of the park, they know something about VNP.

Table 1. Profiles of respondents $(\mathrm{N}=45)$

\begin{tabular}{|c|c|c|}
\hline Respondent characteristics & $\begin{array}{c}\text { Number of } \\
\text { respondents }\end{array}$ & Percentage \\
\hline \multicolumn{3}{|c|}{ Gender } \\
\hline Male & 24 & 53 \\
\hline Female & 21 & 47 \\
\hline \multicolumn{3}{|c|}{ Education status } \\
\hline Primary school education & 16 & 35.6 \\
\hline Secondary school education & 15 & 33.3 \\
\hline College/university education & 1 & 2.2 \\
\hline Without formal education & 6 & 13.3 \\
\hline Technical education & 7 & 16.6 \\
\hline \multicolumn{3}{|c|}{ Age } \\
\hline $18-30$ years old & 24 & 53.3 \\
\hline $31-40$ years old & 11 & 24.4 \\
\hline $41-50$ years old & 3 & 6.7 \\
\hline $60+$ years old & 7 & 15.6 \\
\hline \multicolumn{3}{|c|}{ Perception of respondents towards revenue sharing } \\
\hline In agreement & 40 & 89 \\
\hline Business person/self employed & 5 & 11 \\
\hline \multicolumn{3}{|c|}{ level of satisfaction about revenue sharing } \\
\hline Highly satisfied & 24 & 53.3 \\
\hline satisfied & 10 & 22.2 \\
\hline Dissatisfied & 6 & 13.3 \\
\hline
\end{tabular}

Source: Field data, 2014

This graph shows that the high number of respondents $(89 \%)$ answered that the park management share revenue with residents. Only five respondents (11\%) stated that the revenue was not shared with residents. Referring to the diagram above, it seems that respondents are highly satisfied of the sharing of revenue generated from the park. As seen above, 24 respondents $(53.3 \%)$ answered that they were highly satisfied whereas 10 of the part remaining showed that they were satisfied. But, few of them (6 of 45) said that they were dissatisfied. Those six respondents who said that they were dissatisfied were asked to give the reasons why they said that. The various answers given are listed below. 


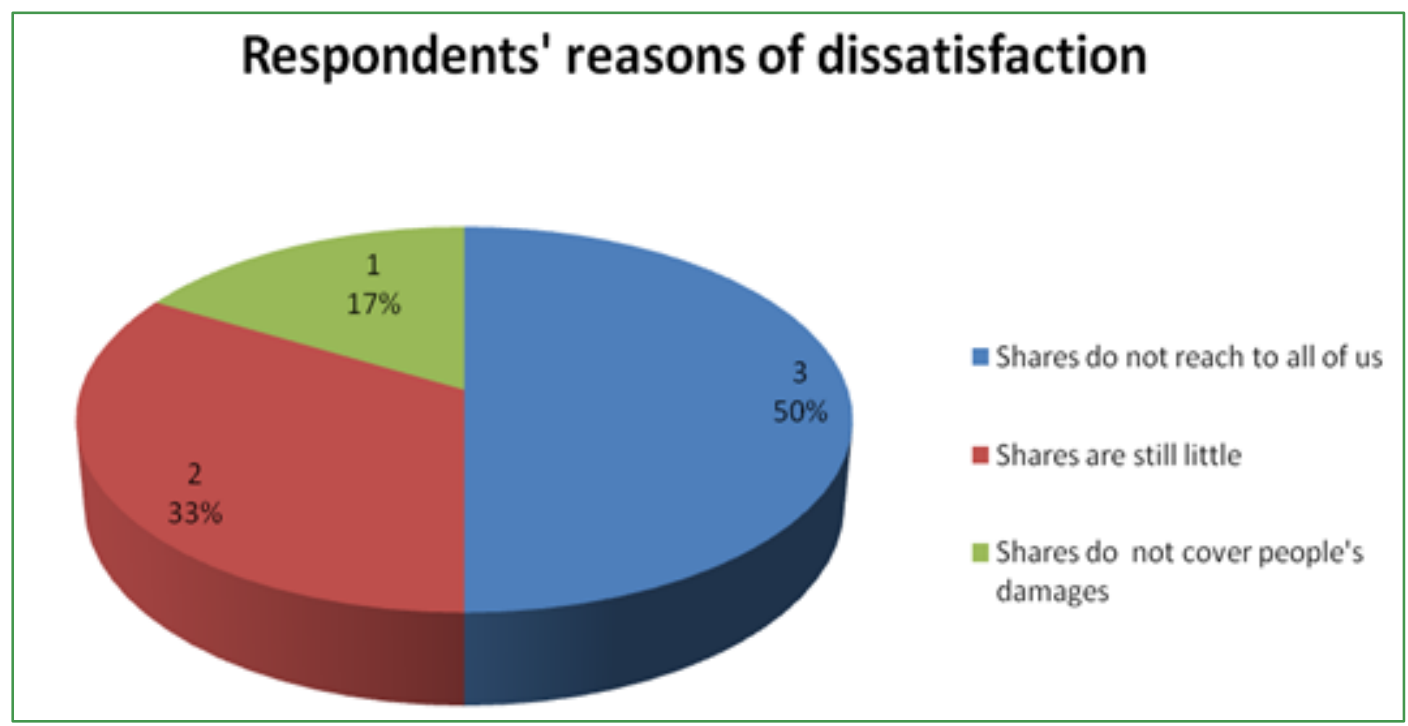

Source: Field data, 2014

Figure 5. Respondents' reasons for dissatisfaction about revenue sharing

The pie chart illustrates that shares do not reach all of concerned people, which makes respondents being dissatisfied; three of six (50\%) proved it well.

Perceptions of residents towards the VNP conservation rules and policies

In this section, two questions were asked to respondents about their perceptions towards the VNP conservation rules and policies. These aimed at saying whether or not rules and policies about VNP conservation existed, and mentioning these policies. They answered as follow: Existence of rules and policies about VNP conservation where $100 \%$ that the rule and policies existed and they included.

Table 3. Examples of policies set for the conservation of VNP

\begin{tabular}{|c|c|c|}
\hline Rules and policies & Frequency & Percentage \\
\hline Setting a wall of separation & 6 & $13.3 \%$ \\
\hline $\begin{array}{c}\text { Creation of small, and medium } \\
\text { enterprises to residents }\end{array}$ & 11 & $24.4 \%$ \\
\hline Revenue sharing & 2 & $4.4 \%$ \\
\hline Infrastructure development & 5 & $11.1 \%$ \\
\hline $\begin{array}{c}\text { Land availability and adequate tenure } \\
\text { Punishment to hunters, bush burners, } \\
\text { and poachers }\end{array}$ & 4 & $8.9 \%$ \\
\hline Increase the investment and financing & 2 & $6.7 \%$ \\
\hline $\begin{array}{c}\text { Capacity building and human } \\
\text { resources motivation }\end{array}$ & 9 & $20 \%$ \\
\hline $\begin{array}{c}\text { Marketing and awareness } \\
\text { reinforcement }\end{array}$ & 3 & $6.7 \%$ \\
\hline Total & 45 & $100 \%$ \\
\hline
\end{tabular}

Source: Primary data, 2014

The table above indicates that the big number of respondents (11 of 45 standing for $24.4 \%$ ) mentioned that one of the policies set up is the creation of small and medium enterprises. Other respondents opted capacity building as a dominant policy in conservation of VNP, whereby 9 respondents mentioned this as their option.

Another policy that comes next was the setting of wall of separation or buffalo wall. It was said by six respondents
$(13.3 \%)$. Other policies were chosen on lowly level. In addition, respondents who chose the creation of SMEs added that through SACOLA, people were created small business and cooperatives to help people getting products that replace those products that they searched from forests as alternatives. This association helped people to improve their livelihood and prevent them from getting into the park to collect firewood, honey, bamboo, poaching, hunting animals for meat, and pastures. For capacity building, one of respondent said that people around the park were trained on the conservation of the park by RDB in partnership with SACOLA through their cooperatives and exhibitions like Gorilla naming ceremony. As preventive measure, few respondents answered that the wall of separation called buffalo wall was built to separate local residents' crops and shelter and wild animals like buffalo in order to prevent them from damaging them.

Roles of residents in conservation activities

The table below is about the roles as answered by respondents.

Table 4. Residents' role in VNP conservation decision making process

\begin{tabular}{|c|c|c|}
\hline $\begin{array}{c}\text { Residents' roles in VNP conservation } \\
\text { decision making process }\end{array}$ & Frequency & Percentage \\
\hline $\begin{array}{c}\text { Interaction and sharing views with the } \\
\text { local government in terms of } \\
\text { conservation of VNP }\end{array}$ & 30 & $66.7 \%$ \\
\hline $\begin{array}{c}\text { Active participation in marketing } \\
\text { VNP tourism potential }\end{array}$ & 3 & $6.7 \%$ \\
\hline $\begin{array}{c}\text { Seek partnership opportunities with } \\
\text { tourism private companies }\end{array}$ & 1 & $2.2 \%$ \\
\hline $\begin{array}{c}\text { Information to park managers about } \\
\text { the people who harm the park }\end{array}$ & 7 & $15.6 \%$ \\
\hline $\begin{array}{c}\text { Attending the conference discussing } \\
\text { about the VNP conservation }\end{array}$ & 4 & $8.9 \%$ \\
\hline No one & 0 & $0 \%$ \\
\hline Total & 45 & $100 \%$ \\
\hline
\end{tabular}

Source: Field survey, 2014 
The major role of residents in VNP conservation decision making process was the interaction and sharing views with the government in terms of conservation of VNP. This role was given by 30 respondents among 45 respondents $(66.7 \%)$, which is the high number. The other role given by 7 respondents (15.6\%) was to inform the park managers about the people who harm the park. These findings show that residents collaborate actively with the local government and shares views about the conservation of VNP. One of respondents among these added: "nowadays, no one can dare to enter the park because it is seriously protected. During the meetings we are informed about the protection and conservation of the park, the advantages of mountain gorillas, then we give our ideas on how we perceive the advices we are given." Another said: "the event of Gorilla Naming Ceremony has opened our mind to conserve the Volcanoes National Park, because we are made aware of the benefit of conserving the park."

In addition, most of the participants in the survey appreciate the role that residents play in the application of conservation policies in the VNP. However, they revealed that few people still get into the park and that measures are being reinforced to continue with reducing those illegal activities.

\section{Deterrents of conservation policies of VNP}

The last section of the questionnaire was based on the challenges that the people who were concerned in the conservation of the park faced while implementing the conservation policies of VNP.

\section{Implementation of conservation policies of VNP}

In this subsection, people were asked to state whether the policies suggested were implemented. Most of respondents perceived the policies as implemented. However, another small portion of respondents perceived it negatively. The pie chart below shows how respondents perceive the implementation of the VNP conservation policies.

When observing the chart above, it is clear that the policies were implemented where 28 respondents $(62 \%)$ revealed their positive perceptions. But 17 of the total number of respondents (38\%) said that the policies were not implemented. Basing on these negative perceptions, led the researcher to ask the challenges that occurred during the implementation of the policies chosen by $\mathrm{RDB}$ and its stakeholders.

Challenges faced in the implementation of VNP conservation policies

Table 5. Challenges faced in the implementation of VNP conservation policies

\begin{tabular}{|c|c|c|}
\hline Challenges faced & Frequency & Perception \\
\hline Human and wildlife conflict & 4 & $8.9 \%$ \\
\hline $\begin{array}{c}\text { Little attention of local residents } \\
\text { to the conservation rules }\end{array}$ & 2 & $4.4 \%$ \\
\hline $\begin{array}{c}\text { Lack of information about the } \\
\text { conservation policies }\end{array}$ & 2 & $4.4 \%$ \\
\hline Lack of motivation & 1 & $2.2 \%$ \\
\hline Forests resources dependency & 8 & $17.8 \%$ \\
\hline No answer & 28 & $62.2 \%$ \\
\hline Total & 45 & $100 \%$ \\
\hline
\end{tabular}

Source: Field data, 2014

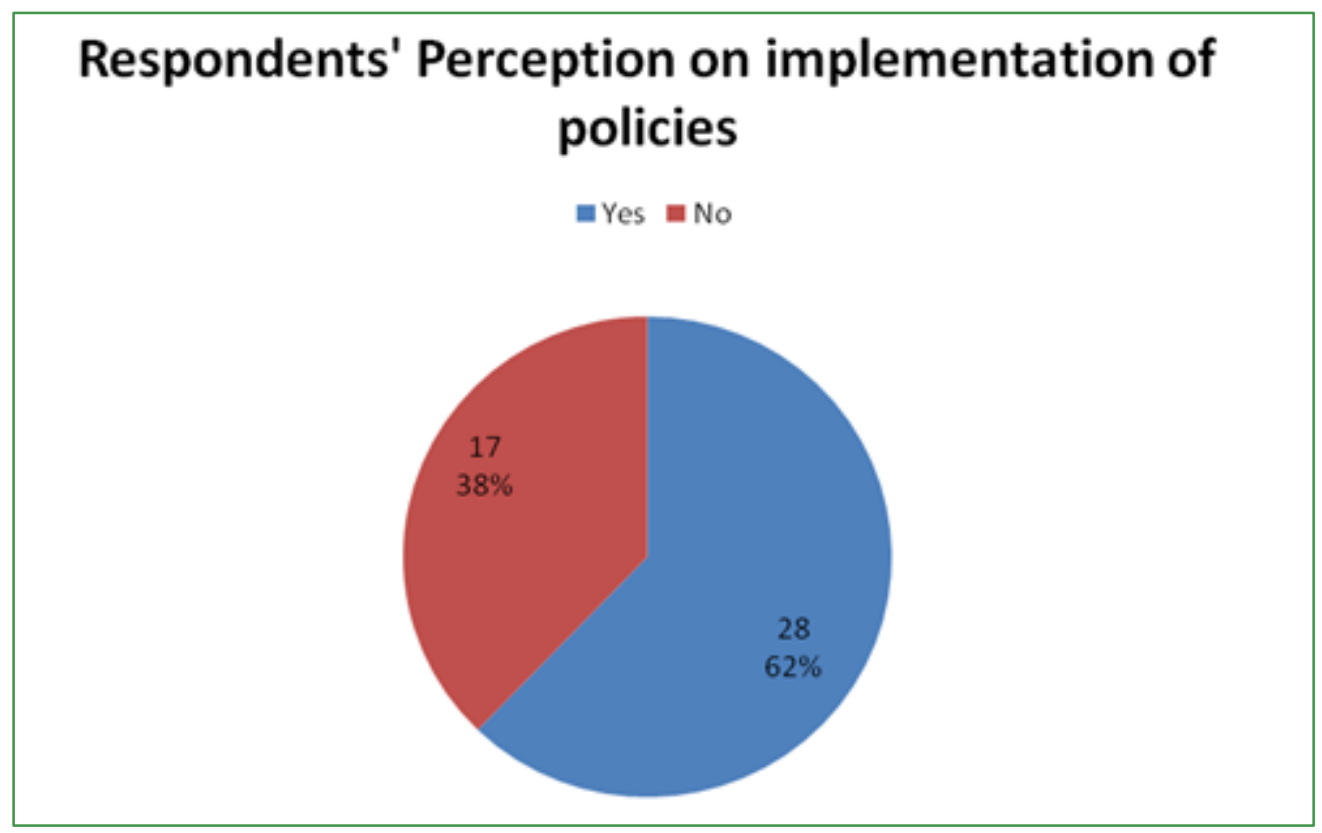

Source: Primary Data, 2014

Figure 6. Respondents' perceptions on Implementation of VNP Conservation policies 
One of these respondents said: "although serious measures were taken, some of people (pygmies) enter illegally in the park to search for different items such as bamboo for shelter, meat, baby gorilla, and others. Another respondent said that the policies were not implemented because residents are not motivated. This motivation was based on the fact that the revenue shared does neither reach to all residents nor cover the damages from the park activities. This absence of motivation led some people to continue with illegal activities within the park such as hunting, collection of bamboos, and poaching. Some of people in Kansoro Village of Kabeza Cell revealed that some pygmies near the park do not participate in the meetings and do not want to change their mindset so as to avoid the wrong activities that harm the park. For these reasons, they remain uninformed about the conservation of the park. These views are similar as those of respondents in Rugwiro Village of Muhabura cell where 2 respondents said that some people pay little attention to the VNP conservation policies. These acts constitute the barriers to the implementation of the VNP conservation policies.

\section{Discussion and Conclusions}

The study was all about the investigation on residents' perceptions about Rwanda's Tourism and Conservation Policies and their implementation around Volcanoes National Park. It was based on Nyange Sector in three cells selected as they were around the VNP. These cells include Kabeza, Muhabura, and Ninda. The objectives were the following: to establish the satisfaction level of local residents towards the Volcanoes National Park rules, to assess the residents' role in conservation and decision making on matter related to VNP and the residents' satisfaction about their role, and to find out existing challenges in the implementation of conservation policies in VNP. People were aware and satisfied of existence of tourism conservation rules and policies about VNP conservation. The people were satisfied of small and medium enterprises they were created in order to prevent people from getting into the park to search for its resources such as meat, bamboo, animal, and other products.

\subsection{Conclusion}

Volcanoes National Park contains the rich biodiversity that attracts many tourists. In order to sustain these rich biodiversity, conservation measures need to be in places well as working with local communities as they are directly and indirectly affected by the activities of the park. The government of Rwanda strives to strengthen the economic development through empowering different economic sectors including tourism. In its vision, it is said that through well-managed marketing, development and public-private partnerships, Rwanda will become established as a leading wildlife and eco-tourism destination and a regional conference hub, with a high quality, diversified tourism product that makes a growing contribution to the overall socio-economic development of the country. Despite being an attractive destination, Volcanoes National Park is facing different threats resulting from human activities including poaching, hunting, bamboo collection, and others even if policies to conserve the VNP were set up. The findings of the study revealed that policies were implemented but challenges still occur. These include the high dependency on the natural resource of the park.

\section{Recommendation to the Study}

If Volcanoes National Park is to remain intact, authentic and attractive top tourists, several conservation tools should be developed in consultation with local residents who implement them at the ground. There is a call to all of national park leaders and local governments to closely work with communities while making conservation measures and policies The tourism revenue sharing policy implementation should be reinforced and should reach the intended poor people in order to empower them creating local business. This will reduce the overdependence of some residents to the park natural resource. The reparation of residents' activities damages caused by the park activities should be done in order to avoid the conflicts between those people and the management of the park. The local government should continue to sensitize all residents in conservation of the park and monitor their activities day and night in order to prevent illegal activities from being done which can harm the park if not controlled. Residents should collaborate with stakeholders, RDB, and local government in terms of conservation of VNP in respecting closely to the policies made for the conservation of the park. They also should inform to the park managers whoever is suspected to cause harm to the park biodiversity.

\section{Implications of the study to the tourism industry}

The above study findings revealed that conservation still faces some challenges even when policies have been put in place. It thus requires creativity and strict supervision of protected areas if national parks are to remain sustainable and generate more income to the national coffer.

\section{Appendix 1: Questionnaire}

\section{UNIVERSITY TOURISM, TECHNOLOGY AND BUSINESS STUDIES (UTB) QUESTIONNAIRE}

Dear Respondent,

We are conducting an academic research entitled "Local community attitude and perceptions towards tourism conservation policies in Rwanda Case of Volcanoes National Park." You have been identified as a resourceful person for this study and hereby requested to spare your 
resourceful time and fill in this questionnaire. The information you provide will be kept strictly confidential and only aggregate figures will be reported. It will be greatly appreciated if you would complete the questionnaire, as your opinion can help improve the conserve volcanoes national park. In case you are interested in the outcome of the study, kindly provide your contact address and kindly return the completed questionnaire to the deliverer. Thank you for your time and effort.

Yours faithfully,

Mr. Kalulu Ronald

Lead Researcher

University of Tourism, Technology and Business Studies (UTB)

Tel +256-782368052/+256-700368052 OR $+250787560649$

Tushabe Emmy

Associate Researcher

University of Tourism, Technology and Business Studies (UTB)

Tel +250782469995

Nsabimana Emmanuel

Associate Researcher

University of Tourism, Technology and Business Studies (UTB)

Tel +250784143786

SECTION A: characteristics of respondents (Please tick the most appropriate option)

1. What is your age group?

\begin{tabular}{|l|c|c|c|c|}
\hline Age (years) & $20-30$ & $31-40$ & $41-50$ & 51 and above \\
\hline & & & & \\
\hline
\end{tabular}

2. What is your gender?

\begin{tabular}{|c|c|}
\hline 1. Male & 2. Female \\
\hline & \\
\hline
\end{tabular}

3. What is your marital status?

\begin{tabular}{|l|l|l|l|l|}
\hline 1.Single & 2. Married & 3.Divorced & 4.Widowed & 5. Separated \\
\hline & & & & \\
\hline
\end{tabular}

4. What is your highest education level?

\begin{tabular}{|c|c|c|c|c|c|}
\hline $\begin{array}{c}1 . \\
\text { None }\end{array}$ & $\begin{array}{c}2 . \\
\text { Primary }\end{array}$ & $\begin{array}{c}3 . \\
\text { secondary }\end{array}$ & $\begin{array}{c}4 . \\
\text { Certificate }\end{array}$ & $\begin{array}{c}5 . \\
\text { Diploma }\end{array}$ & $\begin{array}{c}6 . \\
\text { Degree }\end{array}$ \\
\hline & & & & & \\
\hline
\end{tabular}

\section{RESIDENTS FEELINGS ABOUT REVENUE SHARING}

5. Does the park management share with residents the revenue generated by the park?

\begin{tabular}{|l|l|}
\hline Yes & \\
\hline No & \\
\hline
\end{tabular}

6. If yes, how are you satisfied with those shares?

\begin{tabular}{|c|c|c|}
\hline Dissatisfied & Satisfied & Highly satisfied \\
\hline & & \\
\hline
\end{tabular}

7. If dissatisfied, why?

Please Specify :

\section{PERCEPTION OF RESIDENTS TOWARDS THE VNP CONSERVATION RULES AND POLICIES}

8. Does the VNP have rules and policies regarding its conservation?

\begin{tabular}{|l|l|}
\hline Yes & \\
\hline No & \\
\hline
\end{tabular}

9. If yes, what are they?

\begin{tabular}{|c|c|}
\hline $\begin{array}{c}\text { Setting a wall of separation } \\
\text { residents }\end{array}$ & \\
\hline Revenue sharing & \\
\hline Infrastructure development & \\
\hline Land availability and adequate tenure & \\
\hline Punishment to hunters and poachers & \\
\hline Increase the investment and financing & \\
\hline Capacity building and human resources motivation & \\
\hline Market and awareness reinforcement & \\
\hline
\end{tabular}

\section{ROLE OF RESIDENTS IN VNP CONSERVATION DECISION MAKING PROCESS}

10. As local residents, which role do you play in VNP conservation decision making process?

\begin{tabular}{|c|c|}
\hline $\begin{array}{c}\text { Interaction and Sharing views with the government } \\
\text { in terms of conservation of VNP }\end{array}$ & \\
\hline $\begin{array}{c}\text { Active participation in marketing VNP tourism } \\
\text { potential }\end{array}$ & \\
\hline $\begin{array}{c}\text { Seek partnership opportunities with tourism private } \\
\text { companies }\end{array}$ & $\begin{array}{c}\text { (n) } \\
\text { harm the park }\end{array}$ \\
\hline $\begin{array}{c}\text { Attending the conferences discussing about the VNP } \\
\text { conservation }\end{array}$ & \\
\hline No one & \\
\hline
\end{tabular}

\section{CHALLENGES FACING THE IMPLEMENTATION OF CONSERVATION POLICIES OF VNP}

11. Are conservation policies stated above implemented?

\begin{tabular}{|l|l|}
\hline Yes & \\
\hline No & \\
\hline
\end{tabular}


12. If no, what are the challenges hindered in the implementation of the conservation policies in VNP?

\begin{tabular}{|c|c|}
\hline Land encroachment & \\
\hline Human and wildlife conflict & \\
\hline $\begin{array}{c}\text { Little attention of local residents to the } \\
\text { conservation rules }\end{array}$ & \\
\hline $\begin{array}{c}\text { Lack of information about the conservation } \\
\text { policies }\end{array}$ & \\
\hline Insecurity & \\
\hline Lack of motivation & \\
\hline Forest resources dependency & \\
\hline
\end{tabular}

\section{Appendix 2: Kabeza Cell Head Office}

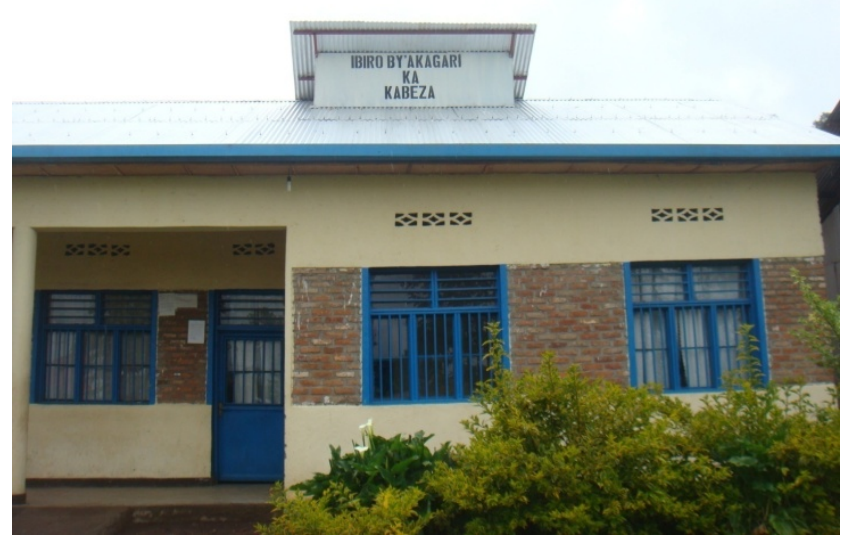

This photo shows the head office of Kabeza Cell. It shares border with Kamwumba, Cyivugiza, and Ninda cells of Nyange sector, Migeshi and Kabeza II of Cyuve sector, and Nyonirima Cell of Kinigi Sector

\section{Appendix 3: Muhabura Cell Head Office}

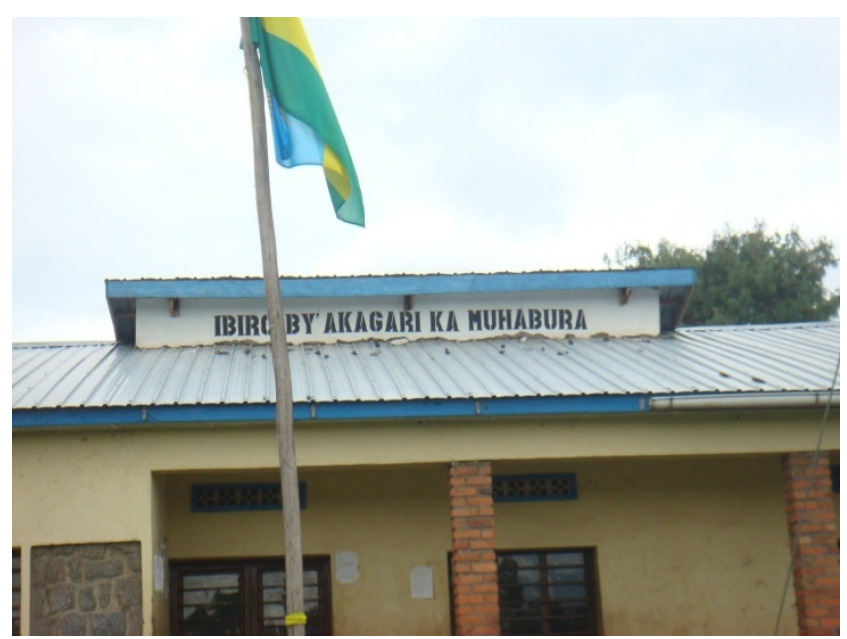

This is the Head Office of Muhabura Cell that shares border with Ninda cell of Nyange Sector, Migeshi of Cyuve sector, and Burera District.

\section{Appendix 4: Ninda Cell Head Office}

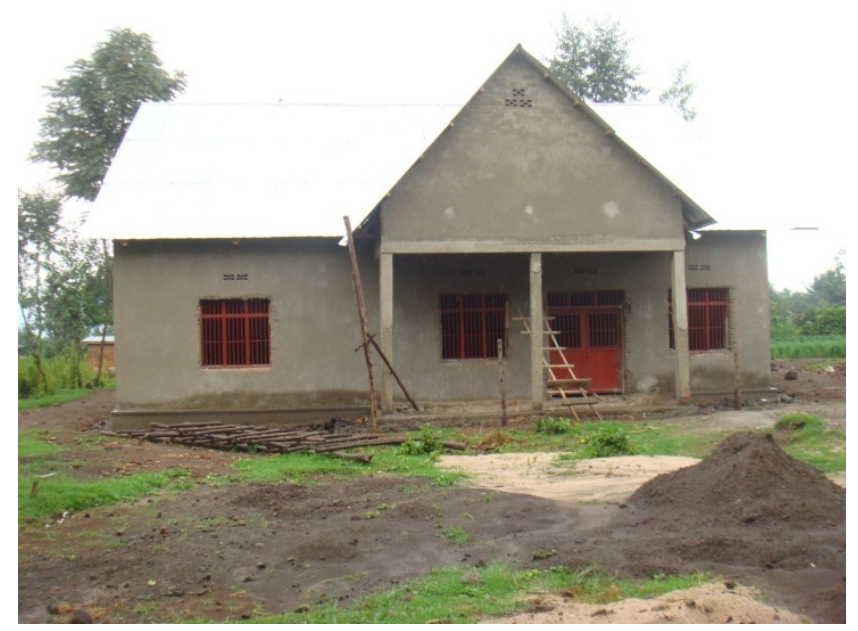

Source: Primary data, 2014

This building under the construction is the head office of Ninda Sector supported by SACOLA. It currently use the building of COOPAV Cooperative in Mararo Village for its daily functions.

Ninda cell shares borders with Muhabura and Kabeza I in Nyange Sector, and Migeshi of Cyuve Sector.

\section{Appendix 5: COOPAV Office}

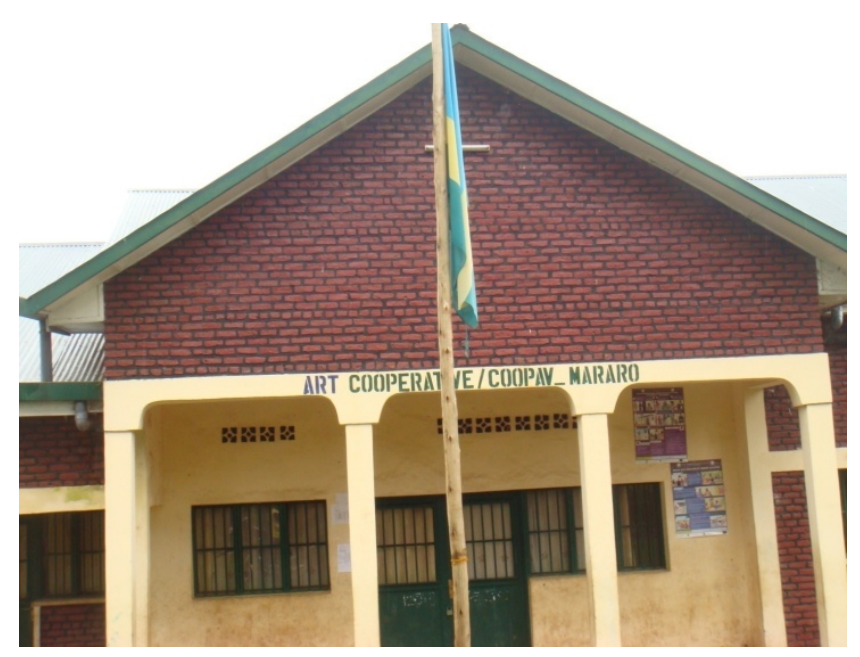

Source: Primary data, 2014

This building is owned by COOPAV cooperative for art. It is also used by Ninda Cell officials for daily functions because its proper office is under construction under support of SACOLA. 


\section{Appendix 6: Some local projects supported by SACOLA}

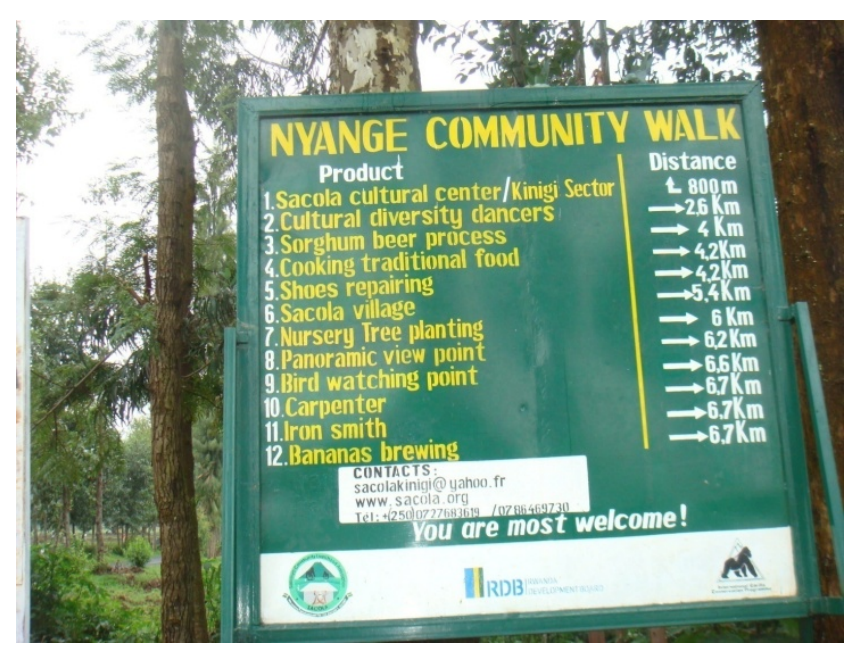

Source: Primary data, 2014

The signpost shows some projects supported by SACOLA for reducing overdependence of local residents and indigenous to VNP natural resources. Through those projects RDB support them with revenue from tourism activities.

\section{REFERENCES}

[1] Adams,W. M., \& Infield, M. (2003).Claims on tourist revenue from a Ugandan National Park. World development, 31(1), 177-190 Barrett C. B. and Arcese (1995), “Are integrated conservation-development projects sustainable?" World Development, 1073-1084.

[2] Blomley, T., Namara, A., McNeilage, A., Franks, P., Rainer, H., Donaldson, A Sandbrook, C. (2010). Assessing Fifteen Years of Integrated Conservation and Development in Southwestern Uganda.

[3] Bookbinder, M. P., Dinerstein, E., Rijal, A., Cauley, H., \&Rajouria, A. (1998). Ecotourism's support of biodiversity conservation. Conservation Biology, 12(6), 1399-1404.

[4] Bunting, B. Sherpa and M. Wright (1991); Annapurna Conservation Area; Nepal's New Approach to Protected Area Management. West. PC and SR Brechin (eds.).

[5] Bush, G. K., Ikirezi, M., Daconto, G., Gray, M., \& Fawcett, K. (2010). Assessing impacts from community conservation interventions around Volcano National Park, Rwanda.

[6] Eagles P., (1992), "The planning and management of environmentally sensitive areas", Longman, London Gossling, S. (1999).

[7] Gray, M., A. McNeilage, K. Fawcett, M. Robbins, B. Ssebide, D. Mbula, and P. Uwingeli (2005), "Virunga Volcanoes range and census," 2003. Joint organizers report. Uganda Wildlife.

[8] Gray, M., McNeilage, A., Fawcett, K., Robbins, M. M., Ssebide, B., Mbula, D., \& Uwingeli, P. (2009). Censusing the mountain gorillas in the Virunga Volcanoes; complete sweep method versus monitoring. African Journal of Ecology, 48(3), 588-599.

[9] Hulme, D. and M. Murphee, (2001), "Community conservation in Africa," in: Hulme, D. and M. Murphee (eds.) African wildlife and livelihoods; the promise and performance of community conservation.

[10] Kalpers, J., Williamson, E. A., Robbins, M. M., McNeilage, A., Nzamurambaho, A., Lola, N., \& Mugiri, G. (2003). Gorillas in the crossfire; population dynamics of the Virunga mountain gorillas over the past three decades. Oryx, 37(03), 326-337.

[11] MacKinnon, J., \& MacKinnon, K. (1986). Review of the protected areas system in the Afrotropical realm. Gland; IUCN/UNEP.

[12] MINITERE (2003). National Strategy and Action Plan for the conservation of Biodiversity in Rwanda, Kigali, Rwanda

[13] Munanura, I. E., Backman, K. F., \& Sabuhoro, E. (2013). Managing tourism growth in endangered species' habitats of Africa.

[14] Plumptre, A., Kayitare, A., Rainer, H., Gray, M., Munanura, I., Barakabuye, N., Namara, A. (2004). The Socio-economic status of people living near protected areas in the Central Albertine rift. WCS, IGCP, CARE Uganda, Kampala, Uganda.

[15] Richards G., Hall D., (2000), "Tourism and sustainable community development", Routledge, New York

[16] Saunders, M., Lewis, P. and Thornhill, A. (2003) Research Methods for Business Students, 3rd ed, Prentice Hall, London Sekhar, U. (2003).

[17] Local community's attitudes towards conservation and wildlife tourism around Sariska Tiger Reserve, India. Journal of environmental Management, 69(4), 339-347.251

[18] Tusabe, R., \& Habyalimana, S. (2010). From Poachers to Park Wardens; Revenue Sharing Scheme as an incentive for environment protection in Rwanda.

[19] Uwingeli, P. (2009), Personal Communication, Chief Park Warden, Volcanoes National Park, 3 November 2009.

[20] Weber, W. (1987). Ruhengeri and its resources; An environmental profile of the Ruhengeri Prefecture, Rwanda. Ruhengeri Resource Analysis and Management Project. 